\title{
Development of the Arctic gas industry and prospects for the Russian LNG market in the Asia-Pacific region
}

\author{
Mikhail Ulchenko ${ }^{1, *}$ \\ ${ }^{1} \mathrm{PhD}$ (Economics), Associate Professor, Leading Researcher, Editorial Department, G. P. Luzin Institute for Economic Studies of the \\ Kola Science Centre of the RAS, 184209, Fersman st., 146, Apatity, Russia
}

\begin{abstract}
The article is devoted to the study of the development of the Arctic gas industry and the prospects of LNG sales in the market of the Asia-Pacific region. It is shown that the largest projects for the production of liquefied natural gas in Russia are concentrated in the Yamal-Nenets Autonomous district "Yamal LNG" and "Arctic LNG - 2". The growth of economies, partial abandonment of nuclear energy and coal contributes to the growth of natural gas consumption in the countries of the Asia-Pacific region. Japan, China and South Korea remain the largest LNG importers. The analysis showed that South Korea and Japan, despite all efforts to reduce energy consumption, are interested in increasing the volume of purchases of Russian liquefied natural gas. To meet their needs, Japanese companies "Jogmeg" and "Mitsui" purchased a $10 \%$ stake in the "Arctic LNG - 2" project for \$ 25 billion. China, having concluded a trade agreement with the United States, will try to meet the growing demand for oil and gas through the supply of American energy resources. However, given the decline in the number of operating rigs in the United States, it is not certain that China will not need additional supplies from other exporters.
\end{abstract}

\section{Introduction}

The high price of energy resources, relatively high rates of economic growth, the desire to improve the environmental situation, as well as extremely low volumes of its own gas production, make the market of the Asia-Pacific region a key target of the largest producers of liquefied natural gas.

As one of the key exporters and producers of natural gas, Russia strives to take a worthy place in the rapidly developing LNG market. The main feature of industrial production of natural gas in Russia is that the vast majority of it is produced in the difficult natural and climatic conditions of the Arctic zone of the Russian Federation. At the same time, most of the exported fuel for many years was intended for the countries of the European Union. However, in recent years, the increased demand for liquefied natural gas in the countries of the Asia-Pacific region, as well as the successful implementation of Russian Arctic LNG projects, have reoriented the direction of Russian exports. China, South Korea, and Japan are interested in increasing Russian gas supplies in the coming years.

\section{Industrial production of Russian Arctic LNG}

Russia is one of the largest importers and producers of natural gas in the world [1]. At the same time, its position in the market of liquefied natural gas was not so strong until recently. However, the implementation of the large Arctic project "Yamal-LNG" allowed it to enter the top five importers of liquefied natural gas - 39.9 billion $\mathrm{m} 3$ by the end of 2019 [2]. Figure 1 shows data on the volume of Russian liquefied natural gas exports in the period from 2014 to 2019 . It is noteworthy that $45 \%$ of the total volume of imported LNG was delivered to the market of the Asia-Pacific region. As part of this project, 3 lines of the plant were built with a total capacity of 7.6 billion $\mathrm{m}^{3}$ each. The fourth line is next in line, the distinctive feature of which is that liquefaction will be carried out using technologies developed in Russia. The design capacity of the fourth line is 1.25 billion $\mathrm{m}^{3}$, and its commissioning should take place in 2020.

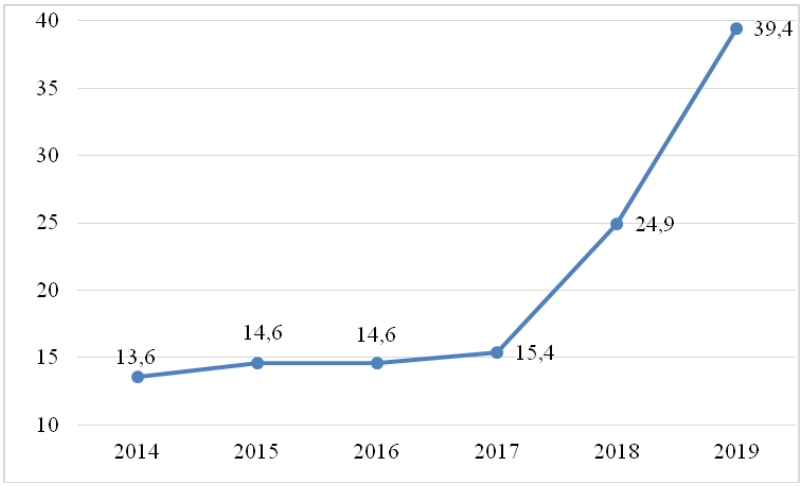

Fig.1. The volume of Russian exports of liquefied natural gas, billion $\mathrm{m}^{3}$

\footnotetext{
* Corresponding author: ulchenko23@,rambler.ru
} 
Thus, the total capacity of "Yamal-LNG" will be 24 billion $\mathrm{m}^{3}$ [3]. The operator is the Russian company PJSC "NOVATEK", whose share in the project is $50.1 \%$, 20\% belongs to the French "Total", $10 \%$ to the Chinese company "CNPC", and another 9.9\% - "Silk Road Fund". However, this is not the only major Russian Arctic project for the production of liquefied natural gas. The next step is the implementation of another project of PJSC "NOVATEK" - "Arctic LNG - 2".

The project also plans to build three lines of the plant with a total capacity of 27.5 billion $\mathrm{m}^{3}$ [4]. Completion of the first line is scheduled for 2022, and launch in 2023. The remaining two lines will be launched in 2024 and 2026. The implementation of two major Arctic projects will allow the Russian Federation to take its rightful place in the rapidly developing LNG market. In order to understand the prospects of Russian Arctic liquefied natural gas in the market of the Asia-Pacific region, it is necessary to analyze the market needs.

\section{Basic needs and industrial production of natural gas in the Asia-Pacific region}

According to experts forecasts, the liquefied natural gas market will surpass the pipeline market by 2035 [5]. At the same time, the market in the Asia-Pacific region already accounts for about $75 \%$ of the world's LNG volume, and it is growing rapidly [2]. The main drivers of growth are China, South Korea and Japan.

In their struggle to improve the environmental situation, countries in the Asia-Pacific region are switching to cleaner fuels - natural gas and renewable energy sources. As a result, the share of coal in total energy consumption is gradually decreasing, from 2017 to 2019 from 49 to $48 \%$. In addition, after the tragic events that occurred at the Japanese nuclear power plant "Fukushima 1", Japan and South Korea explicitly announced a gradual reduction in the number of operating nuclear reactors, as a result, the volume of natural gas consumption has increased significantly compared to 2010. Figure 2 shows data on the volume of natural gas consumption by countries in the Asia-Pacific region in the period from 2010 to 2019.

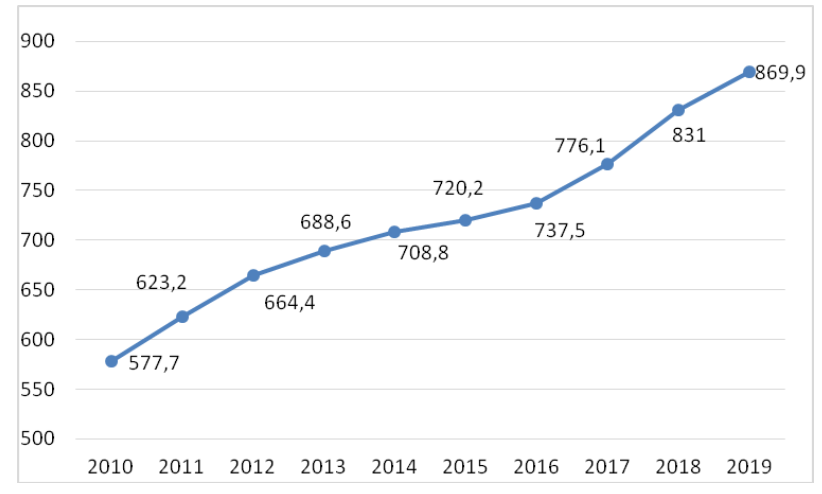

Fig.2. Natural gas consumption in the Asia-Pacific region, billion $\mathrm{m}^{3}$ [2]

China remains the leader in the growth of natural gas consumption throughout this period. One of the world's two largest economies is constantly in need of additional energy supplies, and serious environmental problems are prompting local authorities to switch local power plants from coal to cleaner fuels. Despite the fact that domestic gas production in the country is constantly growing, the growth rate of consumption is much higher than the growth rate of production, as shown in figure 3 . To meet growing needs, China has to constantly increase the volume of natural gas imports. Moreover, gas is delivered to the country, both via gas pipelines and in the form of LNG. The key suppliers of liquefied natural gas to China in 2019 were Australia-38.9 billion $\mathrm{m}^{3}$, Qatar$11.4 \mathrm{~m}^{3}$, Malaysia-10.0 $\mathrm{m}^{3}$, Indonesia-6.2 billion $\mathrm{m}^{3}$, Russia-3.4 billion $\mathrm{m}^{3}$, the United States- 0.4 billion ${ }^{3} 3$ [2] and others.

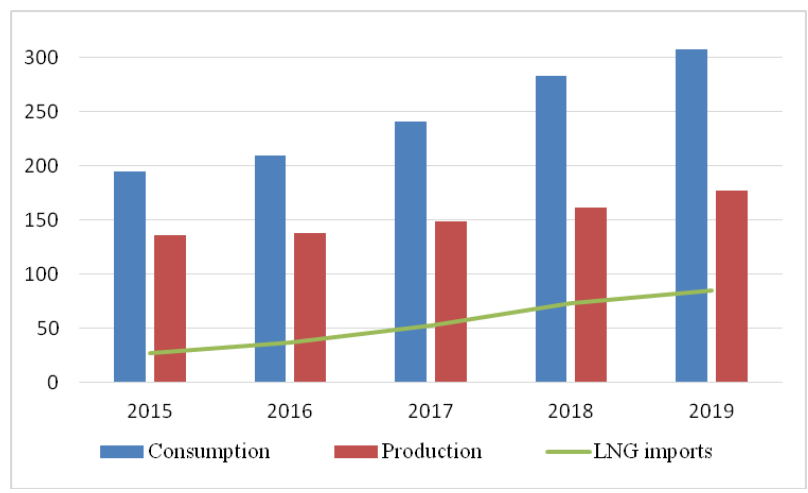

Fig.3. China, natural gas consumption and production, and LNG imports, billion $\mathrm{m}^{3}$ [2]

Despite the fact that the US share of China's total consumption and imports is very small, it is American shale gas that can fill China's LNG terminals in the next two years. The trade war that lasted between the two countries for almost a year and a half, and was expressed in the mutual imposition of $25 \%$ duties on a number of goods, apparently came to an end. In January 2020, a trade agreement was reached, according to which the Chinese side undertakes to purchase American energy resources for 2020 and 2021 for an amount exceeding 50 billion dollars [6]. Taking into account the fact that the cost of imports of American oil and natural gas, until 2017 , reached the level of 17-18 billion dollars, under the new agreement, the volume of deliveries should increase three times. Given that the prices of oil and natural gas fell significantly between 2017 and 2020, it can be assumed that the increase in supplies may be even more significant. Most likely, this will lead to the fact that some of the suppliers will lose part of their share in the Chinese market of liquefied natural gas.

According to the results of last year, the volume of Chinese imports amounted to about 85 billion $\mathrm{m}^{3}$, we are talking only about liquefied natural gas [2]. However, the us side exported about 48 billion $\mathrm{m}^{3}$ of gas per year [2]. Given the fact that the country has recorded a historic decline in the number of operating gas drilling rigs, from 170 to 80 , we can assume that we should not expect an increase in shale gas production. Most likely, the volume of gas production will decrease, which will also affect the volume of imports. However, even if we 
take last year's results as a starting figure, the US will not be able to meet China's demand for liquefied natural gas.

However, the very fact of concluding a trade agreement, as well as the discovery of a new large natural gas field in Sichuan province (about 1 trillion $\mathrm{m}^{3}$ ) only confirms the assumption that the struggle for the Chinese LNG market in the next 2 years will be very serious.

Japan has been the largest importer of liquefied natural gas in the world for many years. According to the data shown in figure 4 , the volume of LNG consumption and imports increased significantly in 2011, after the tragic events that occurred at the "Fukushima 1" nuclear power plant.

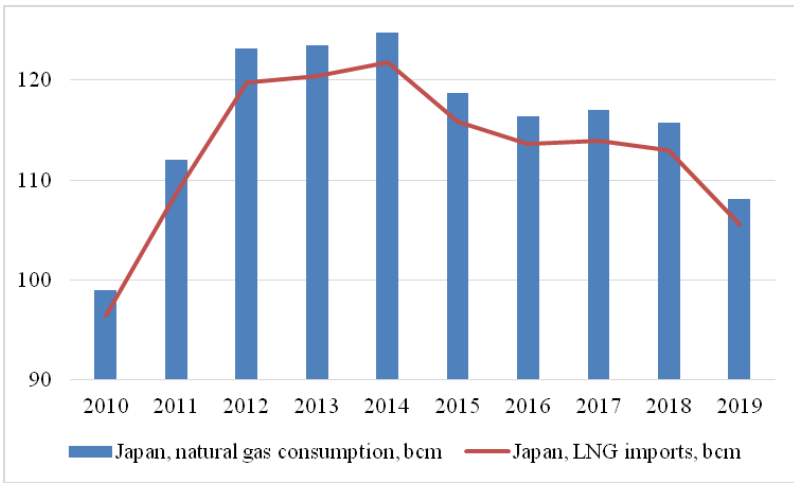

Fig.4. Japan, natural gas production and LNG imports, billion $\mathrm{m}^{3}[2]$

It was then that the decision was made to abandon the use of nuclear power. As a result, since 2011, the production of energy at nuclear power plants has been constantly decreasing, and in 2014 it completely stopped. However, the new government of Japan considered that the country could not do without a peaceful atom, and in 2015 the process of restarting nuclear reactors began. As a result of the newly developed plan, by 2030 , at least $30 \%$ of the energy received in the country should be accounted for by nuclear power [7].

The development of technologies that allow obtaining energy from renewable sources, as well as the restart of nuclear reactors, has reduced the consumption of liquefied natural gas in Japan from 123.5 billion $\mathrm{m}^{3}$ by the end of 2014 to 108 billion $\mathrm{m}^{3}$ by the end of 2019 . At the same time, the volume of LNG imports also decreased significantly, from 122 billion $\mathrm{m}^{3}$ to 106 billion $\mathrm{m}^{3}$, over the same years [2]. The key suppliers of liquefied natural gas to Japan in 2019 were Australia41.0 billion $\mathrm{m}^{3}$, Malaysia-11.9 billion $\mathrm{m}^{3}$, Qatar- $11.4 \mathrm{~m}^{3}$, Russia-8.7 billion $\mathrm{m}^{3}$, Indonesia-5.7 billion $\mathrm{m}^{3}$ the United States-5.0 billion $\mathrm{m}^{3}$ [2] and others. However, in order to diversify transportation routes and suppliers, the Japanese government has decided to increase the volume of purchases of liquefied natural gas in Russia. Given the difficult relations between the countries, due to the division of disputed territories, according to Japan, this step does not seem quite logical. Nevertheless, the Japanese government sees the Russian Federation as a strategic partner in ensuring energy security. This was confirmed by the purchase of a $10 \%$ stake in a major Russian Arctic project for the production of liquefied natural gas - "Arctic LNG - 2", in the summer of 2019. The transaction cost was about 25.5 billion us dollars. the Japanese side is represented by Jogmeg and Mitsui. A similar share in the project is held by the French company "Total", as well as the Chinese "CNODC"and "CNOOC" [4]. The Russian side is represented by PJSC "NOVATEK", whose share is $60.1 \%$, while if the company receives a decent offer from the Japanese side, its share may increase to $20 \%$. At the same time, it should be noted that natural gas production will be performed at the "Morning" field, which has proven reserves of 1.89 trillion $\mathrm{m}^{3}$ [8].

Thus, we can say that there are all prerequisites for the share of Russian Arctic LNG in the energy market of Japan to increase, and in the coming years.

The dynamics of natural gas consumption in South Korea is multidirectional, however, over the past 10 years, the volume of consumption has increased by more than $20 \%$ (figure 5) [2].

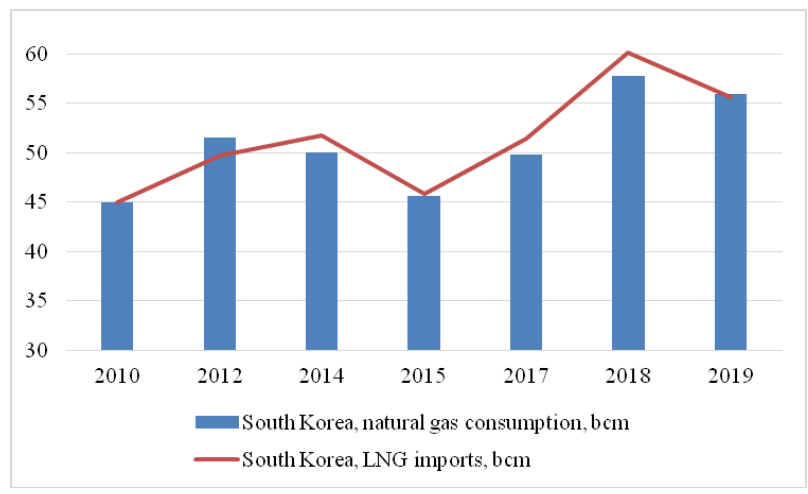

Fig.5. South Korea, natural gas production and LNG imports, billion $\mathrm{m}^{3}[2]$

Given that there are no significant natural gas reserves in the country, all needs are met by importing liquefied natural gas. The main reason for the increase in natural gas consumption was economic growth, as well as the partial abandonment of coal in favor of gas. The main suppliers of liquefied natural gas are Qatar-15.3 billion $\mathrm{m}^{3}$, Australia-10.6 billion $\mathrm{m}^{3}$, the United States-7.2 billion $\mathrm{m}^{3}$, Malaysia-6.6 billion $\mathrm{m}^{3}$, Oman-5.6 billion $\mathrm{m}^{3}$, Indonesia-3. 2 billion $\mathrm{m}^{3}$, Russia-3.1 billion $\mathrm{m}^{3}$.

Despite the fact that the share of Russian LNG in the energy market of South Korea is small, only $5 \%$, it is necessary to note the positive dynamics. Thus, by the end of 2018, the volume of Russian LNG supplies amounted to 2.95 billion $\mathrm{m}^{3}$, and by the end of $2019-$ 3.1 billion $\mathrm{m}^{3}$. At the same time there are prerequisites for their increase:

- first, South Korea relies on renewable energy sources and liquefied natural gas, while nuclear power plants are planned to be gradually decommissioned. At the first stage, the construction of 6 new reactors was frozen, and the "Kori 1" nuclear power plant, which had been 
operating for almost 40 years, was closed. The main reason for abandoning nuclear power is the example of the Fukushima - 1 disaster. At the same time, if about 150 thousand people lived in the immediate vicinity of the Japanese nuclear power plant, then, for example, more than 4 million people live within a radius of $30 \mathrm{~km}$ from the "Busan" nuclear power plant.

- secondly, South Korea's desire to diversify the supply routes of liquefied natural gas and suppliers. At the same time, the government has explicitly stated its desire to purchase Russian and American LNG. However, given the reduction in the number of operating gas rigs in the United States, as well as the need to comply with the trade agreement with China, the prospects for increasing the supply of American shale gas to the South Korean market look unlikely.

It is not so difficult to replace the outgoing capacity of nuclear power plants with liquefied natural gas. Due to increased competition in the LNG market, the price of gas has significantly decreased, while South Korea, by mid-2020, has 5 terminals with a total capacity of about 120 billion $\mathrm{m}^{3}$, which are only $45 \%$ loaded. According to S\&P Global Platts Analytics [9] in South Korea, the volume of coal imports has decreased by more than $20 \%$ since the beginning of 2020 , while 28 coal-fired power plants have been closed. During the same time period, the volume of liquefied natural gas imports increased by more than $30 \%$. The main reason is the decline in LNG prices. Given the fact that the cost of Russian liquefied natural gas is much lower than that of Australian and American $[10,11]$, we can say that domestic companies have real prospects for increasing LNG sales to South Korea this year.

The study was conducted under the theme "the Interaction of global, national and regional factors in the economic development of the North and Arctic zone of the Russian Federation" on the state assignment FITS KSC RAS.

\section{References}

1. Ministry of energy of the Russian Federation. Production of natural and associated petroleum gas. Available online: https://minenergo.gov.ru/node/1215 (2020)

2. British Petroleum. Official periodicals: Statistical review of world energy 2020. Available online: https://www.bp.com/content/dam/bp/businesssites/en/global/corporate/pdfs/energyeconomics/statistical-review/bp-stats-review-2020full-report.pdf. (2020)

3. PJSC «NOVATEK». The project «Yamal LNG». Available online: http://www.novatek.ru/ru/business/yamal-lng/. (2020)

4. PJSC «NOVATEK». The project «Arctic LNG-2». Available online: http://www.novatek.ru/ru/business/arctic-lng/ (2020)
5. U.S. Energy Information Administration. Natural Gas Monthly. Available online: https:/www.eia.gov/naturalgas/monthly/pdf/ngm_al l.pdf (2020)

6. News agency «EurAsia Daily». The USA and China have signed a historic agreement, ending the trade war. Available online: https://eadaily.com/ru/news/2020/01/15/ssha-ikitay-zaklyuchili-istoricheskoe-soglasheniezavershiv-torgovuyu-voynu (2020)

7. Electronic periodical «Oil and Capital». Japan: back and forth to nuclear power. Available online: https:/oilcapital.ru/article/general/17-08-

2017/yaponiya-vpered-nazad-k-atomnoy-energetike172e9bfe-f9f6-4f14-a182-8f8dc3111200 (2020)

8. Ministry of energy of the Russian Federation. Production of natural and associated petroleum gas. Available https://minenergo.gov.ru/node/1215 (2020)

9. Electronic periodical edition «Vedomosti». East Asia is actively switching from coal to gas. Available online: https:/www.vedomosti.ru/business/articles/2020/04/ 21/828604-vostochnaya-aziya-uglya-gaz (2020)

10. N. Didenko, D. Skripnuk, O. Mirolyubova, V. Merkulov, V. Sevashkin, E. Samylovskaya, International Conference on Information Networking, 217-222 (2018)

11. S. Kozmenko, M. Ulchenko, IOP Conference Series: Earth and Environmental Science 302(1), 012123 (2019) 